\title{
Announcing the 2007 AAPS National Biotechnology Conference
}

\section{June 24-27, 2007, San Diego Convention Center, San Diego, CA}

The American Association of Pharmaceutical Scientists (AAPS) will sponsor a National Biotechnology Conference with the FDA and American Institute of Chemical Engineers (AIChE) acting as cosponsors. The conference will be held June 24-27, 2007 at the San Diego Convention Center in San Diego, CA.

The conference will cover a broad range of innovative biotechnology topics and contemporary issues devoted to advancing health through innovations in biotherapeutics. The plenary session currently includes presentations from Stanley Crooke of Isis Pharmaceuticals and Daria Mochly-Rosen from Stanford University. Specific program topics include: "Phase IV Requirements for Biologics"; "Population PK of Monoclonal Antibodies"; "Smart Drug Delivery Systems: Interfacing Biotechnology with Nanotechnology to Improve Drug Therapy"; "Progress in Epigenetic Therapies"; "Innovations in Excipient Selection for Biopharmaceutical Formulations Development"; "Embryonic Stem Cells in Drug Discovery"; "Aggregates of Proteins and Their Conjugates"; "Data Analysis for Anti-product Antibody Assessment"; "Intracellular Trafficking and Processing of Macromolecules"; "Quality by Design"; "Novel Vaccine Delivery Systems"; "Designing the Next Generation of Therapeutic
Antibodies"; "Immunogenicity Considerations"; and numerous other timely topics of interest to regulatory, academic, and pharmaceutical scientists.

The scientific program is comprised of a combination of indepth oral presentations, workshops, and poster sessions. In addition, there will be 3 hot topic sessions on Exenatide Pharmacology, the Cytokine Storm Following phase I Administration of TGN1412, and In-study Run Acceptance Criteria for Ligand Binding Assays. Preceding the conference there will be a repeat of the popular 2-day Ligand Binding Assay Training course, 3 excellent Open Forums and a short course titled "Where Did My Biologic Go - And Why?." The meeting concludes with short courses on "Controlled Released Formulation Strategies for Protein and Peptide Therapeutics"; and "Critical Path Initiative Role of PK/PD for Biotechnology Products." This conference will also feature a Career Center with major companies exhibiting at the conference. A preliminary program as well as information on the conference venue and registration procedures may be found at www. aapspharmaceutica.com/nationalbiotech.

For more information contact: Chair, Ron Bowsher, $\mathrm{PhD}$, Chief Scientist LINCO Research, at ron_bowsher@millipore. com or Co-chair, Giovanni M. Pauletti, PhD, Associate Professor at University of Cincinnati, College of Pharmacy at gm.pauletti@uc.edu. 